\title{
Blood Bank Reagent
}

National Cancer Institute

\section{Source}

National Cancer Institute. Blood Bank Reagent. NCI Thesaurus. Code C133335.

Diagnostic substances manufactured for commercial distribution used to characterize and determine the acceptability of blood products for transfusion purposes. These include reagent red blood cells, blood grouping reagents, antibody to HBsAg, etc. 